\title{
Prevalence of hypertension and major cardiovascular risk factors in healthy residents of a rural region in south-eastern Poland - 1997-2008/9
}

\author{
Daniel Płaczkiewicz'1, Marek Puźniak', Andrzej Kleinrok ${ }^{1,2}$ \\ ${ }^{1}$ Department of Cardiology, The Pope John Paul II Hospital, Zamosc, Poland \\ ${ }^{2}$ Department of Physiotherapy and Pedagogy, Zamosc University of Management and Administration, Poland. \\ Płaczkiewicz D, Puźniak M, Kleinrok A. Prevalence of hypertension and major cardiovascular risk factors in healthy residents of a rural region \\ in south-eastern Poland - 1997-2008/9. Ann Agric Environ Med. 2016; 23(3): 476-481. doi: 10.5604/12321966.1219191
}

\begin{abstract}
Introduction and objective. The aim of this study was to show the prevalence of hypertension and major risk factors of cardiovascular disease among healthy adults in an agricultural region of south-eastern Poland, and the changes which have occurred in this area during the 12-year follow-up.

Materials and method. 1,233, mostly rural inhabitants of Zamosc County without previous history of diabetes and CVD were subjected to analysis. Prevalence of hypertension and major cardiovascular risk factors were evaluated. Changes in the prevalence of risk factors between 1997 - 2008 were analyzed.

Results. $33.0 \%$ of the examined population are active smokers, and there was a 1.8-fold increase $(p=0.0009)$. The percentage of people with hypercholesterolemia between 1997 - 2008/9 increased almost 2 -fold $(p<0.0001)$ and now it is $62.3 \%$. The number of people with high blood pressure decreased nearly by a half $(46 \%, \mathrm{p}<0001)$ and it is currently $25.8 \%$. Improper waist circumference was observed in $32.8 \%$ of the population (33.1\% women, $26.5 \%$ men). Abdominal obesity decreased among men (48\%; $p=0.0008$ ) and rural residents (29\%, $p=0.01)$. In comparison with 1997, in 2008-2009, the cardiovascular risk assessed using SCORE tables increased. The percentage of people with high-risk $(\geq 5 \%)$ almost tripled in the general population $(p=0.0183)$ and increased 4 -fold in men $(p=0.0145)$.

Conclusions. Detection of hypertension in the rural region in which the survey was carried out is still too low. Actions against tobacco addiction should be a major component of health-education programmes for the rural areas of south-eastern Poland.
\end{abstract}

- Key words

risk factors, cardiovascular diseases, rural population

\section{INTRODUCTION}

Regardless of the achievements of modern cardiology, cardiovascular disease (CVD) prevention remains a basic tool for the reduction of morbidity and mortality. Although premature mortality due to CVD in Poland is decreasing systematically, particularly due to the observed lifestyle changes among Poles, it still remains one of the highest in Europe and continues to be the leading cause of death in the country. Therefore, it seems of great importance to increase the efforts to educate society in terms of health care and introduce more effective prevention programmes. In order to undertake rational actions, it is vital to have current knowledge on the occurrence of particular risk factors. In order to obtain this knowledge, epidemiological studies are carried out. Such large-scale studies have been conducted several times in Poland, with their crowning achievement being the NATPOL 2011 study (preliminary results published in 2011), which demonstrated the prevalence of major risk factors and their changes that occurred in Poland during the last decade [1]. The prevalence of both hypertension (HA) [2] and other CVD risk factors, including smoking [3], in various regions of Poland, mostly explained by varying degrees of urbanization, have already been documented.

Address for correspondence: Daniel Płaczkiewicz, Department of Cardiology, The Pope John Paul IInd Hospital, Zamosc, Poland

E-mail:d.placzkiewicz@interia.pl

Received: 02 December 2012; accepted: 04 February 2014
The presented study with to respect the Lublin region is especially unique. According to the data derived from the WOBASZ study, a few years ago the frequency of occurrence of HA and the incidence of the metabolic syndrome in this region was the lowest in Poland. However, there is lack of large epidemiological studies focusing on the rural population. The aim of this study was to analyze the prevalence of HA and the main risk factors for cardiovascular diseases among healthy adults in a typical Polish agricultural region, and to attempt to assess the changes that have occurred in that area over the last 12 years.

Although the identified risk factors are counted in dozens, the classic ones, such as: hypertension, dislipidemia, abdominal obesity, diabetes, and smoking in combination with psychosocial factors, still cause over $90 \%$ of heart attacks [4] and almost the same number of strokes [5]. Possible early detection and effective elimination of at least the major modifiable risk factors still seem to be the most effective ways to reduce the epidemic of cardiovascular disease. Therefore, an attempt was made to assess risk factors and focus on the healthy population who were the main recipients of prevention programmes.

\section{MATERIALS AND METHOD}

1,233 , mostly rural inhabitants of Zamosc County, without previous history of diabetes and CVD, were subjected to 
the analysis. The primary source of the collected data was a number of surveys carried out on individuals and gathered from them by medical staff during outdoor events promoting healthy lifestyle organized by the Department of Cardiology of The Pope John Paul II Hospital in Zamosc in 1997 and 2008. An additional source of the surveys came from the programme of Cardiovascular Disease Prevention (PPChUK) collected in 2008 and 2009 by GP doctors in health centres, spanning the area of the county (outside the actual city of Zamosc). People diagnosed with HA, diabetes, and other CVD, people younger than 35 and older than 69 years were excluded in order to unify the inclusion criteria. The presence of the risk factors for cardiovascular disease, the results of measurements of blood pressure, serum total cholesterol (TC) and glucose (glucose was not evaluated in the 1997 studies), as well as survey data on physical activity, were analyzed. Systolic blood pressure (SBP) of $140 \mathrm{~mm} \mathrm{Hg}$, and diastolic blood pressure (DBP) of $90 \mathrm{~mm} \mathrm{Hg}$ were considered abnormal.

In 1997, diagnosis was based on a single measurement. In 2008 and 2009, the average value of 3 measurements made during a single visit was calculated. Hyperglycaemia was defined as $126 \mathrm{mg} / \mathrm{dL}(7.0 \mathrm{mmol} / \mathrm{L})$ for fasting glucose and $200 \mathrm{mg} / \mathrm{dL}(11.1 \mathrm{mmol} / \mathrm{L})$ for casual glucose, hypercholesterolaemia as $190 \mathrm{mg} / \mathrm{dL}(5.0 \mathrm{mmol} / \mathrm{l})$ for TC. Improper waist size was considered at $102 \mathrm{~cm}$ for men and $88 \mathrm{~cm}$ for women. In 1997, the respondents were only asked about the subjective evaluation of their physical activity. Due to the fact that all the respondents found it satisfactory, the results were not included in the further analysis. In the group of subjects in 2008/9, the recreational physical activity lasting at least $30 \mathrm{~min}$. and exercising at least 4 times a week was considered satisfactory.

In most cases, the obtained data was sufficient to assess cardiovascular risk using the SCORE algorithm, in the version optimized for the Polish population [6]. The incidence of the occurrence of HA, and (in the available scope) of individual risk factors in 1997 and 2008/9 was asessed.

Statistical analysis of the data was performed using the programme Statistica, version 7.1. To assess the significance of the differences between the groups, respectively, to the type and the characteristics of the data, the Pearson chisquared test and the Mann-Whitney test were applied. In all comparisons, $\mathrm{p} \leq 0.05$ was the statistically significant value.

\section{RESULTS}

From the initial number of 870 questionnaires collected during outdoor medical events, after excluding those with any history of diabetes, hypertension, and cardiovascular disease, 479 were left. The study included 121 people surveyed in 1997 (44.5\% of the collected questionnaires) and 358 tested in 2008 (59.9\% of the collected questionnaires). PPChUK provided an additional 754 surveys for the years 2008 2009. Among 1,233 respondents interviewed, there were 738 women (59.9\%) and 495 men (40.1\%) (Tab. 1).

The risk factors for cardiovascular disease between 1997 2008/2009 were compared (Tab. 2, 3). The observed negative changes included the increase in the number of smokers and the number of people with hypercholesterolaemia. The percentage of people at high cardiovascular risk assessed by the SCORE tables also increased. The reduction in the
Table 1. Baseline characteristics of subjects ( $n=1233 ; 1997-121,2008 / 9$ - 1112)

\begin{tabular}{llcc}
\hline \multirow{2}{*}{ Gender } & & $\mathbf{1 9 9 7}$ & $\mathbf{2 0 0 8 / 9}$ \\
\hline \multirow{2}{*}{ Place of residence } & Female & 80 & 658 \\
\cline { 2 - 4 } & Male & 41 & 454 \\
\hline \multirow{2}{*}{ Mean age \pm SD [years] } & Village & 91 & 966 \\
\cline { 2 - 4 } & city up to 70,000 inhabitants & 30 & 146 \\
\cline { 2 - 4 } & Total & $\mathbf{4 6 . 2} \pm \mathbf{7 . 3}$ & $\mathbf{4 5 . 5} \pm \mathbf{7 . 5}$ \\
\cline { 2 - 4 } & male gender & $46.4 \pm 7.2$ & $45.3 \pm 7.7$ \\
\cline { 2 - 4 } & Rural & $45.9 \pm 7.6$ & $45.9 \pm 7.2$ \\
\cline { 2 - 4 } & Urban & $46.4 \pm 7.6$ & $44.8 \pm 7.0$ \\
\hline
\end{tabular}

SD - standard deviation

number of abdominal obesity among men, and the decrease of average values of blood pressure, particularly SBP, and the percentage of people with unrecognized $\mathrm{HA}$, can be rated as positive changes.

There was a 1.8 -fold increase in the number of active smokers ( $p=0.0009$ ). $33.0 \%$ of the examined population were active smokers (22.1\% of women and $48.7 \%$ men). This growth was mainly caused by 2.2 -fold increase in the percentage of smokers among rural inhabitants $(\mathrm{p}=0.0002)$. The number of smokers increased comparably among men (1.7-fold, $\mathrm{p}=0.0171)$ and women (1.8-fold, $\mathrm{p}=0.0461)$. However, the average number of cigarettes smoked daily did not change (17.4 vs. $15.9 ; \mathrm{p}=0.465)$. The percentage of people with hypercholesterolaemia between 1997 - 2008/9 increased almost 2 -fold $(\mathrm{p}<0.0001)$ to the level of $62.3 \%$ (women $58.8 \%$; men $-67.4 \%$ ). This phenomenon was not observed among the urban population. The greatest increase has been noticed among women $(2.1$-fold; $\mathrm{p}<0001)$ and rural residents $(2$-fold; $\mathrm{p}<0001)$. The average concentration of TC among people with abnormal values ( 223 vs $229 \mathrm{mg} / \mathrm{dl}$; $\mathrm{p}=0.1696$ ) did not change, although in the group of the rural population a slight increase was recorded ( 218 vs $228 \mathrm{mg} / \mathrm{dl}$; p=0.0426).

Improper waist circumference is observed in $32.8 \%$ of the population (33.1\% women; $26.5 \%$ men). Abdominal obesity decreased among men (48\%; $\mathrm{p}=0.0008)$ and rural residents ( $29 \% ; \mathrm{p}=0.01)$. The changes in the general population do not seem to indicate any significance $(p=0.0515)$. The number of obese people, taking into consideration body mass index (BMI), did not undergo any alternation $(\mathrm{p}=0.1684)$. The average BMI also remained unchanged (26.9 vs. 26.5; $\mathrm{p}=0.289$ ).

The number of people with high blood pressure decreased by nearly a half $(46 \%$; $\mathrm{p}<0001)$ and currently totals $25.8 \%$ of the population of healthy individuals (20.8\% women; $33 \%$ men). Although this decrease was also observed, it did not reach statistical significance only in the group of city dwellers as well as among women, when the study was restricted to assessing only the DBP. Average SPB values decreased (133.4 vs. $126.9 \mathrm{~mm} \mathrm{Hg}$; $<0.0001$ ), but not among the urban population. The average normal SBP (122.6 vs. $120.6 \mathrm{~mm}$ $\mathrm{Hg}$; $\mathrm{p}=0.1367$ ) and abnormal SBP (148.8 vs. $150.7 \mathrm{~mm} \mathrm{Hg}$; $\mathrm{p}=0.323$ ) did not change. The average values of DBP in the general population remained unaltered (80.4 vs $79.7 \mathrm{~mm} \mathrm{Hg}$; $\mathrm{p}=0.1544)$, although their decline among men was revealed ( $85.5 \mathrm{vs} 82.0 \mathrm{~mm} \mathrm{Hg}, \mathrm{p}=0.0063$ ). The average values of normal DBP among the population did not change (75.6 vs $76.7 \mathrm{~mm}$ $\mathrm{Hg}$; $=0.4771$ ). Nevertheless, there was a slight increase in 
Table 2. Selected risk factors in a healthy population of rural areas in south-eastern Poland between 1997-2008/9

\begin{tabular}{|c|c|c|c|c|c|c|c|c|}
\hline & & \multirow{2}{*}{$\begin{array}{c}1997 \\
\mathrm{n}\end{array}$} & \multicolumn{3}{|c|}{$2008 / 9$} & \multicolumn{2}{|c|}{ difference } & \multirow[b]{2}{*}{$\mathrm{p}^{*}$} \\
\hline & & & $\%$ & $\mathrm{n}$ & $\%$ & $\begin{array}{c}\text { absolute } \\
(\Delta \%)\end{array}$ & $\begin{array}{c}\text { relative } \\
(\%)\end{array}$ & \\
\hline & total & $22 / 121$ & 18.2 & $366 / 1108$ & 33.0 & +14.8 & +81.3 & 0.0009 \\
\hline & females & $10 / 80$ & 12.5 & $145 / 655$ & 22.1 & +9.6 & +76.8 & 0.0461 \\
\hline \multirow[t]{5}{*}{ Smoking } & males & $12 / 41$ & 29.3 & $221 / 453$ & 48.7 & +19.4 & +66.2 & 0.0171 \\
\hline & rural & $14 / 91$ & 15.4 & $332 / 962$ & 34.5 & +19.1 & +124.0 & 0.0002 \\
\hline & urban & $8 / 30$ & 26.7 & $34 / 146$ & 23.3 & -3.4 & -12.7 & 0.6925 \\
\hline & total & $50 / 120$ & 41.7 & $363 / 1106$ & 32.8 & -8.9 & -21.3 & 0.0515 \\
\hline & females & $29 / 79$ & 36.7 & $243 / 655$ & 33.1 & +3.6 & +9.8 & 0.9459 \\
\hline \multirow[t]{4}{*}{ Abdominal obesity** } & males & $21 / 41$ & 51.2 & $120 / 451$ & 26.5 & -24.7 & -48.2 & 0.0008 \\
\hline & rural & $42 / 91$ & 46.2 & $315 / 961$ & 32.8 & -13.4 & -29.0 & 0.0100 \\
\hline & total & $82 / 121$ & 67.8 & $650 / 1108$ & 58.6 & -9.2 & -13.6 & 0.0513 \\
\hline & females & $50 / 80$ & 62.5 & $347 / 656$ & 52.9 & -9.6 & -15.4 & 0.1037 \\
\hline \multirow[t]{5}{*}{ Overweight/obesity (BMI $\geq 25$ ) } & males & $32 / 41$ & 78.0 & $303 / 452$ & 66.9 & -11.1 & -14.2 & 0.1430 \\
\hline & rural & 62 / 91 & 68,1 & $570 / 963$ & 59,2 & $-8,9$ & -13.1 & 0.0961 \\
\hline & urban & $20 / 30$ & 66,7 & $80 / 145$ & 55,2 & $-11,5$ & -17.2 & 0.2469 \\
\hline & total & $39 / 121$ & 32.2 & $691 / 1108$ & 62.3 & +30.1 & +93.5 & $<0.0001$ \\
\hline & females & $22 / 80$ & 27.5 & $385 / 655$ & 58.8 & +31.3 & +113.8 & $<0.0001$ \\
\hline \multirow[t]{3}{*}{$\mathrm{TC} \geq 190 \mathrm{mg} / \mathrm{dl}$} & males & $17 / 41$ & 41.5 & $306 / 453$ & 67.4 & +25.9 & +62.4 & 0.0008 \\
\hline & rural & $30 / 91$ & 33.0 & $620 / 962$ & 64.4 & +31.4 & +95.2 & $<0.0001$ \\
\hline & urban & $9 / 30$ & 30.0 & $71 / 146$ & 48.6 & +18.6 & +62.0 & 0.0620 \\
\hline \multirow[t]{5}{*}{ Systolic BP $\geq 140 \mathrm{mmHg}$} & males & $24 / 41$ & 58.5 & $121 / 454$ & 26.6 & -31.9 & -54.6 & $<0.0001$ \\
\hline & rural & $41 / 91$ & 45.1 & 199/966 & 20.6 & -24.5 & -54.3 & $<0.0001$ \\
\hline & urban & $9 / 30$ & 30.0 & $35 / 146$ & 24.0 & -6.0 & -20.0 & 0.4874 \\
\hline & total & $34 / 121$ & 28.1 & $182 / 1112$ & 16.4 & -11.7 & -41.6 & 0.0012 \\
\hline & females & $15 / 80$ & 18.8 & $82 / 658$ & 12.5 & -6.3 & -33.6 & 0.1160 \\
\hline \multirow[t]{5}{*}{ Diastolic BP $\geq 90 \mathrm{mmHg}$} & males & $19 / 41$ & 46.3 & $100 / 454$ & 22.0 & -24.3 & -52.5 & 0.0005 \\
\hline & rural & 28/91 & 30.8 & $156 / 966$ & 16.1 & -14.7 & -47.7 & 0.0004 \\
\hline & urban & $6 / 30$ & 20.0 & $26 / 146$ & 17.8 & -2.2 & -11.0 & 0.7768 \\
\hline & total & $58 / 121$ & 47.9 & $287 / 1112$ & 25.8 & -22.1 & -46.1 & $<0.0001$ \\
\hline & females & $30 / 80$ & 37.5 & $137 / 658$ & 20.8 & -16.7 & -44.6 & 0.0008 \\
\hline \multirow[t]{5}{*}{ High BP *** } & males & $28 / 41$ & 68.3 & $150 / 454$ & 33.0 & -35.3 & -51.7 & $<0.0001$ \\
\hline & rural & $48 / 91$ & 52.7 & $240 / 966$ & 24.8 & -27.9 & -52.9 & $<0.0001$ \\
\hline & urban & $10 / 30$ & 33.3 & $47 / 146$ & 32.2 & -1.1 & -3.3 & 0.9031 \\
\hline & total & $4 / 99$ & 4.0 & 107/899 & 11.9 & +7.9 & +197.5 & 0.0183 \\
\hline & females & $2 / 67$ & 3.0 & $11 / 523$ & 2.1 & -0.9 & -30.0 & 0.6434 \\
\hline \multirow[t]{3}{*}{ SCORE $\geq 5 \%$} & males & $2 / 32$ & 6.3 & $96 / 376$ & 25.5 & +19.2 & +304.8 & 0.0145 \\
\hline & rural & $3 / 73$ & 4.1 & $89 / 772$ & 11.5 & +7.4 & +180.5 & 0.0518 \\
\hline & urban & $1 / 26$ & 3.8 & $18 / 127$ & 14.2 & +10.4 & +273.7 & 0.1457 \\
\hline
\end{tabular}

* - Pearson's chi-squared test; ** - waist circumference $\geq 102 \mathrm{~cm}$ in men and $\geq 88 \mathrm{~cm}$ in women; *** - Systolic BP $\geq 140 \mathrm{mmHg}$ and/or Diastolic BP $\geq 90 \mathrm{mmHg}$ BMI - Body Mass Index; TC - total cholesterol; BP - blood pressure

the mean DBP among people with abnormal values (92.6 vs $94.9 \mathrm{~mm} \mathrm{Hg}$; $\mathrm{p}=0.0183$ ).

In comparison with 1997, in 2008/2009 (taking into account the examined population), the cardiovascular risk assessed using SCORE tables increased. The percentage of people with high-risk $(\geq 5 \%)$ almost tripled in the general population $(\mathrm{p}=0.0183)$ and increased 4 -fold in men $(\mathrm{p}=0.0145)$. In the case of the rural population, the growth (almost 3-fold) did 
Table 3. Selected risk factors in a healthy population of a rural area in south-eastern Poland between 1997-2008/9 (quantifiable variables)

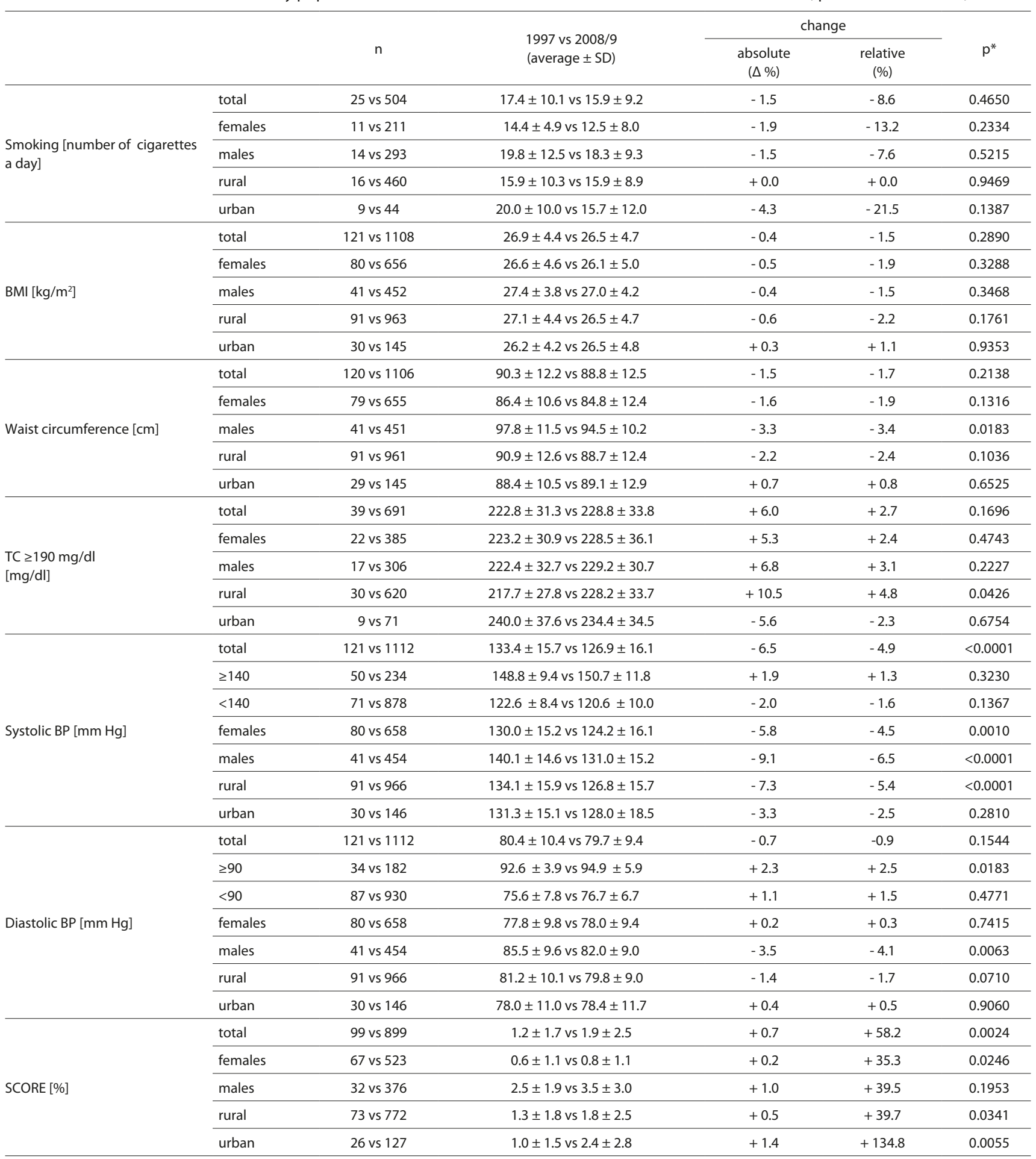

* - Mann-Whitney U test.

SD - standard deviation; BMI - Body Mass Index; TC - total cholesterol; BP - blood pressure.

not reach statistical significance $(\mathrm{p}=0.0518)$. The average value of the SCORE increased 1.6-fold in the general population $(\mathrm{p}=0.0024), 1.4$-fold in women $(\mathrm{p}=0.0246), 1.4$ fold in the rural population $(\mathrm{p}=0.0341)$ and 2.3 -fold in the urban population $(\mathrm{p}=0.0055)$.

$1.1 \%$ of the respondents in 2008/9 had hyperglycaemia (high fastum glucose in most cases). Only $9.6 \%$ of the surveyed individuals in 2008/9 declared satisfactory physical activity.

\section{DISCUSSION}

The presented study evaluated the prevalence of major CVD risk factors in an agricultural region of south-eastern Poland. A significant reduction of the percentage of people with high blood pressure in the area deserves attention. In the opinion of the authors, this is the result, first of all, of a significant improvement in the detection of hypertension in the rural population. In the examined population, the HA prevalence 
in 1997 was slightly higher than $44 \%$ of the NATPOL II study of the same year [7]. The incidence of occurring of HA in 2008/9, however, was significantly lower than that observed in the WOBASZ study carried out between 2003 - 2005 (on average, $36 \%$ : women $-32.9 \%$, men $-42.1 \%$ ). Comparison of the presented results with the part of WOBASZ study carried out for the Lublin region (HA - 24\% - men and women) indicates a more frequent occurrence in the population of $\mathrm{HA}$ in men and less common among women [2]; however, direct comparison with the results of Polish epidemiological studies may only be approximate. The main studies referred to the entire population of adults, including those with diagnosed and treated HA (although in most cases, not effectively), they also differed in the methods of measurement, and before 1997 the definition of HA varied. On the other hand, a decrease in the incidence of unrecognized HA was observed, which corresponded with the trends observed in the general population. According to the latest available data (NATPOL 2011), 32\% of the population of Poland currently suffers from HA $-29 \%$ of women and $35 \%$ of men [1].

The significant increase in the percentage of smokers is alarming, especially among men and the rural population. The NATPOL III PLUS study conducted in 2002 established the number of active smokers to be about $34 \%$ of adult Poles [8], and in this context the presented data from 1997 seem to be slightly lower, which may be a consequence of the relatively small group. The WOBASZ study estimated the number of active smokers in Poland as $25 \%$ of women and $42 \%$ of men, a result that differed from the one obtained for the Lublin province only in the case of women (23\%) [3]. Nowadays, according to the GATS study (2009/10), 27\% of adult Poles (33.5\% of men and $21 \%$ of women) smoke every day. Additionally, the study distinguishes a group of occasional smokers, about $3 \%$ of men and women. In total, everyday and occasional smokers constitute $30.3 \%$ of the healthy population - including $36.9 \%$ of men and $24.4 \%$ of women [9]. The results presented in the current study indicating a higher percentage of male smokers, may result from the low level of education in most cases (according to the GATS $47.4 \%$ of men with vocational education in Poland smoke cigarettes, in the presented study population this percentage reached $39.0 \%$ in 1997 and $61.4 \%$ in 2008/9), and from the fact that the majority of the respondents live in rural areas (GATS - 35.7\% of smokers in this group). Thus, a narrower age range was taken into account and included only healthy people in the study [1]. The results of this study may also be shaped in the presented way because of the material status of the population of the eastern provinces of Poland, especially the rural inhabitants, and due to easier access to cheaper cigarettes illegally imported from the east than in other regions. In the presented study, the average number of smoked cigarettes per day is comparable to other publications: 18 for men and 14 for women (18 and 12.5 , respectively, in Lublin province) in the WOBASZ study, 18 for men and 16 for women, according to the GATS $[1,3]$.

The prevalence of high levels of TC in 1997, as also in the case of smoking, might be lower. This hypothesis may be supported by the significantly higher percentage of hypercholesterolaemia in the NATPOL III PLUS study $(60.7 \%)$ [7]. The values reported in the presented study between 2008 - 2009 are comparable for men and slightly higher for women than in the WOBASZ study $(67 \%$ - men;
$64 \%$ - women). The current results, however, are much higher when compared with the results of the WOBASZ study for the Lublin province (57\% - men; $51 \%$ - women) [10]. This may indicate a broader scale of the problem of hypercholesterolaemia among the population in the rural areas than the results show.

The percentage of people with abdominal obesity in the study group was lower than the Polish average (40.4\% women, $28.3 \%$ of men in the WOBASZ study); in the case of women, the percentage was also lower than the average for Lublin province $(37.5 \%$ in the WOBASZ study). The results concerning men in the WOBASZ study were poor (20.9\%), although the prevalence of abdominal obesity in men decreases. Between 1997 - 2009, the incidence of abnormal weight gain did not change, and the recorded decreasing tendency did not reach statistical significance. Obesity among men was more frequent than in the national population and the province of Lublin (respectively $61.0 \%$ and $53.8 \%$ in the WOBASZ study). Obesity among women occurred more often than in the national population, as well as in the Lublin province (respectively, $48.1 \%$ and $52.0 \%$ in the WOBASZ study) [11].

The risk of death from cardiovascular causes, evaluated throughout a 10-year period in accordance with the SCORE algorithm, increased significantly as a result of the increase in this risk among men which, in turn, was a consequence of the increase in the percentage of active smokers. The high risk in the presented study group is even more than twice as likely than in the results of the studies carried out by other authors analyzing the data obtained from PPChUK in other regions of Poland [12].

\section{CONCLUSIONS}

1) In the study of a potentially healthy population (without a recognized CVD), 25\% of the study population and about $33.3 \%$ of males had elevated blood pressure, which proves that the detection of HA in the region in which the survey was carried out is still too low.

2) The increasing prevalence of active smoking in the study group indicates that the actions against tobacco addiction should be a major component of the health-education programmes for the rural areas of south-eastern Poland.

3) The increased prevalence of risk factors, especially smoking and hypercholesterolaemia, results in a significant increment of the cardiovascular risk among the population (a high 10-year risk of death from cardiovascular causes concerns $25 \%$ of males), which is higher than observed in many other regions of the country.

\section{REFERENCES}

1. Matyjaszczyk P, Hoffmann K, Bryl W. Epidemiologia wybranych czynników ryzyka chorób układu krążenia. Przegl Kardiodiabetol. 2011; 6(4): 255-62.

2. Polakowska M, Piotrowski W, Tykarski A, Drygas W, Wyrzykowski B, Pająk A, et al. Nałóg palenia tytoniu w populacji polskiej. Wyniki programu WOBASZ. Kardiol Pol. 2005; 63: S626-31.

3. Tykarski A, Posadzy-Małaczyńska A, Wyrzykowski B, Kwaśniewska M, Pająk A, Kozakiewicz K, et al. Rozpowszechnienie nadciśnienia tętniczego oraz skuteczność jego leczenia u dorosłych mieszkańców naszego kraju. Wyniki programu WOBASZ. Kardiol Pol. 2005; 63: S614-9. 
4. Yusuf S, Hawken S, Ounpuu S, Dans T, Avezum A, Lanas F, et al; INTERHEART Study Investigators. Effect of potentially modifiable risk factors associated with myocardial infarction in 52 countries (the INTERHEART study): case-control study. Lancet. 2004 Sep 11-17; 364(9438): 937-52.

5. O’Donnell MJ, Xavier D, Liu L, Zhang H, Chin SL, Rao-Melacini P, et al; INTERSTROKE investigators. Risk factors for ischaemic and intracerebral haemorrhagic stroke in 22 countries (the INTERSTROKE study): a case-control study. Lancet. 2010 Jul 10; 376(9735): 112-23.

6. Podolec P, Kopeć G, Gruchała M, Rynkiewicz A. Ocena ryzyka sercowonaczyniowego. W: Podolec P. (red.). Podręcznik Polskiego Forum Profilaktyki. Tom 1. Medycyna Praktyczna, Kraków 2007; 157-65.

7. Podolec P, Karch I, Pająk A, Kopeć G, Broda G, Drygas W, et al. Najważniejsze polskie programy epidemiologiczne i prewencyjne. W: Podolec P. (red.). Podręcznik Polskiego Forum Profilaktyki. Tom 1. Medycyna Praktyczna, Kraków 2007; 103-10.

8. Zdrojewski T, Bandosz P, Szpakowski P, Konarski R, Manikowski. A, Wołkiewicz E, et al. Rozpowszechnienie głównych czynników ryzyka chorób układu sercowo-naczyniowego w Polsce. Wyniki badania NATPOL PLUS; Kardiol Pol. 2004; 61 (supl. IV): IV1-IV26.

9. Globalny sondaż dotyczący używania tytoniu przez osoby dorosłe (GATS). Polska 2009-2010. Ministerstwo Zdrowia, Warszawa 2010.

10. Pająk A, Wiercińska E, Polakowska M, Kozakiewicz K, KaczmarczykChałas K, Tykarski A, et al. Rozpowszechnienie dyslipidemii u mężczyzn i kobiet w wieku 20-74 lat w Polsce. Wyniki programu WOBASZ. Kardiol Pol. 2005; 63: 6 (supl. 4): S620-5.

11. Biela U, Pająk A, Kaczmarczyk-Chałas K, Głuszek J, Tendera M, Wawrzyńska $M$, et al. Częstość występowania nadwagi i otyłości u kobiet i mężczyzn w wielu 20-74 lat. Wyniki programu WOBASZ. Kardiol Pol. 2005; 63(supl. IV): S632-5.

12. Pędziński B, Kurianiuk A, Pędziński W, Szpak A. Ocena zagrożenia chorobami układu krążenia w oparciu o realizację programu profilaktyki w podstawowej opiece zdrowotnej. Probl Hig Epidemiol. 2011; 92(3): 397-404. 